\title{
Animal mobility in Chalcolithic Portugal: Isotopic analyses of cattle from the sites of
} Zambujal and Leceia

Elizabeth Wright ${ }^{1,2}$, Anna J. Waterman ${ }^{3}$, David W. Peate ${ }^{4}$, Michael Kunst ${ }^{5}$, João Luis Cardoso ${ }^{6}$, 5 Cleia Detry $^{7}$

${ }^{1}$ Institution where work was undertaken: University of Sheffield, Department of Archaeology, Minalloy

9 House, 10-16 Regent Street, Sheffield, S1 3NJ, UK. e.wright@ sheffield.ac.uk

$11{ }^{2}$ Present address: Universität Basel, Integrative Prähistorische und Naturwissenschaftliche Archäologie 12 (IPNA), Spalenring 145, CH-4055 Basel Switzerland elizabeth.wright@unibas.ch (corresponding 13 author)

$15{ }^{3}$ Mount Mercy University, Department of Natural and Applied Sciences, 150 Basile Hall, Cedar Rapids, 16 Iowa 52402 USA. awaterman@ mtmercy.edu

$18{ }^{4}$ University of Iowa, Department of Earth \& Environmental Sciences, 115 Trowbridge Hall, Iowa City, IA 1952242 USA. david-peate@uiowa.edu

$21{ }^{5}$ Deutsches Archäologisches Institut, Madrid, Instituto Arqueológico Alemán, Madrid, Calle Serrano, 159, 22 E - 28002 Madrid, Spain. michael.kunst@ dainst.de

$24{ }^{6}$ Universidade Aberta (Lisboa), ICArEHB, and Centro de Estudos Arqueológicos do Concelho de Oeiras 25 (CMO), Portugal. cardoso18@netvisao.pt

$27{ }^{7}$ UNIARQ - Centro de Arqueologia da Universidade de Lisboa, Faculdade de Letras da Universidade de 28 Lisboa, Alameda da Universidade 1600-214 Lisbon, Portugal. cdetry@ gmail.com

\section{Abstract}

32 This paper outlines the results of strontium isotopic analyses from cattle recovered at the 33 Chalcolithic fortified settlement sites of Castro do Zambujal and Leceia (Estremadura, Portugal). 
34 The Portuguese Chalcolithic (c. 3000-1900BC) was a pivotal time of social and economic 35 change with evidence of increasing social complexity resulting in the formation of hierarchical settlements. With these changes came the emergence of long-distance exchange networks and more complex population movements and interactions. Domesticated animals would have played an important role in these emerging economies, and it is assumed that animals migrated with, and were exchanged by, humans as part of these new networks. While direct evidence of these networks is still limited in this region, new methodologies have the potential to expand our knowledge of animal mobility and exchange. This study uses ${ }^{87} \mathrm{Sr} /{ }^{86} \mathrm{Sr}$ ratios in tooth enamel to identify potential non-local animals at these two settlements. Results indicate that Leceia may have had a higher proportion of non-local animals than Zambujal and had a wider catchment area for its stock, suggesting variations in settlement economies across relatively short distances in this region. These results have important implications for our understanding of animal management at Portuguese Chalcolithic sites, and the involvement of animals in the emerging economies of the time.

Keywords: Iberia; Zambujal; Leceia; Copper Age; strontium isotopes; mobility; fauna

\section{Introduction}

The Portuguese Chalcolithic (c. 3000 - 1900BC) was a time of significant social and economic change, with evidence of the expansion of complex settlements and exchange networks (cf. Cardoso, 2007; Gonçalves, 1999; Lillios, 1995; Uerpmann, 1995; Valera et al., 2017). Domesticated animals played an important role in these economies, and the archaeological record demonstrates that people commonly raised domesticated cattle, pigs, sheep and goats for meat and secondary products (Harrison 1985; Valente and Carvalho, 2014). It is assumed that domesticated animals moved with humans, and were sold or exchanged by people as part of these new networks. However, direct evidence of these exchanges is still limited in this region. In the last decade, radiogenic isotope studies $\left({ }^{87} \mathrm{Sr} /{ }^{86} \mathrm{Sr}\right.$ ) have provided a means of

63 identifying migrant human and animals in the Iberian peninsula (Carvalho et al., 2016; Díaz-del-

64 Río, 2017; Diaz-Zorita Bonilla, 2013; Díaz-Zorita Bonilla et al., 2018; Waterman et al., 2014) 
and elsewhere in the world (cf. Knudson et al., 2016; Madgwick et al., 2017; Price et al., 2015; Zhao, 2015). In this paper we outline the results of new strontium isotopic analyses from cattle recovered from the Chalcolithic fortified settlement sites of Castro do Zambujal (Zambujal) and Leceia (both in the Estremadura region) and use this data to identify migrant animals within these settlements.

\subsection{Social complexity and exchange networks in Chalcolithic Portugal}

72 The Chalcolithic period in Portugal saw the rise of large ditched-enclosed, fortified hilltop, and 73 walled settlement types. The archaeological record for this time suggests that with the rise of 74 these complex settlements, long and short distance exchange networks emerged (Cardoso, 2003; 75 Gonçalves, 2000; 2001; Jorge, 2000). Alongside these important socio-economic changes there 76 is variation in site type and function, especially between regions (e.g. Cardoso, 2007; Gonçalves 77 et al., 2013); with the establishment of new large fortified sites, mostly in the Estremadura 78 region. The appearance of new types of material culture also in this region, made of materials such as copper, slate, variscite, amphibolite and ivory, has provided strong evidence of the establishment of long-distance exchange networks (e.g. Cardoso and Carvalhosa, 1995; Cardoso and Schuhmacher, 2012; Cardoso et al., 2013: Gauß, 2015; Lillios, 1997; Müller et al., 2007;

82 Odriozola et al., 2010: Odriozola et al., 2013; Roberts, 2008; Schuhmacher et al., 2009;

83 Schuhmacher, 2012; Schuhmacher, 2017). Archaeological data suggests that some of these 84 materials may have been travelling from areas of southern Iberia, or even northern Africa, into 85 the Estremadura region (Schumacher et al., 2009). Using strontium isotopes, a number of studies have now found direct evidence of human migrants into the Estremadura region. The isotopic

87 signature of these migrants indicates that some of them may have also travelled in from areas of 88 southern Iberia (such as the Alentejo region) possibly as part of these exchange networks 89 (Carvalho et al., 2016; Waterman et al., 2014). It is likely that these migrants were bringing 90 domesticated animals with them as they entered new regions, but to date no study focusing on 91 animal mobility in the Estremadura region has been completed.

\subsection{Animal husbandry in Chalcolithic Portugal}

94 The variations between site types across the region are clearly reflected in the animal remains 95 recovered at settlement sites (Valente and Carvalho, 2014). Fortified sites in the Estremadura 
96 region tend to yield large faunal assemblages, dominated by the three main domesticated animals 97 (cattle, sheep/goat and pig), with evidence for the use of secondary products (i.e. milk, wool, and 98 traction) (Cardoso and Detry, 2002; von den Driesch and Boessneck, 1976), whereas smaller

99 unfortified sites have yielded larger proportions of wild species, indicating a different approach 100 to animal exploitation, as part of a more mobile type of existence (e.g. Cabaço, 2010; Correia, 101 2015; Davis and Mataloto, 2012; Moreno-Garcia and Sousa, 2013; Valente 2013). The two sites 102 included in this study, Leceia and Zambujal, are two of the largest well-known fortified sites in 103 the Estremadura region (Kunst, 2017; Becker and Flade-Becker, 2017). Both of their 104 assemblages show a preponderance of domestic species, with only small proportions of wild 105 species. The use of secondary products, as seen at Portuguese fortified sites such as these, 106 reflects the intensification in animal husbandry seen across Iberia at this time. This 107 intensification has long been linked to the formation of networks for exchanging animals and 108 animal products (e.g. Harrison 1985).

\section{Strontium isotope ratios and landscapes}

111 The strontium isotope signature of a geographic region is controlled by the nature of the 112 underlying geology (rock lithology) and permeates its landscape and groundwater. This signature 113 is absorbed into the biological tissues of local plants and animals (Faure and Powell, 1972; Gilli 114 et al., 2009). In animals, strontium isotopes are incorporated into tooth and bone through 115 ingestion of water and food. This is due to a physiological process in which $\mathrm{Sr}$ substitutes for 116 calcium in the mineral component (hydroxyapatite) of hard tissues (Bentley, 2006; Ericson, 117 1985; Sealy et al., 1991; Schroeder et al., 1972:496). Unlike carbon, nitrogen and oxygen 118 isotopes that are used in many archaeological studies of prehistoric diet, once incorporated into 119 biological tissues, strontium isotopes do not fractionate (i.e. no change in ${ }^{87} \mathrm{Sr} /{ }^{86} \mathrm{Sr}$ ), when passed 120 from prey to consumer. Therefore, an organism's strontium isotope signature directly reflects the 121 bioavailable strontium in its environmental range, rather than its trophic level (Graustein, 1989). 122 Due to how Sr infiltrates biological hard tissues during formation, humans and animals residing 123 in the same territorial ranges and consuming only local plants and animals, should exhibit similar $124{ }^{87} \mathrm{Sr} /{ }^{86} \mathrm{Sr}$ signatures (Tommasini, 2018). In contrast, humans and animals should exhibit 125 differences in strontium isotope ratios between regions that are geologically distinctive. When 126 sufficient geologic heterogeneity is present across regional landscapes, humans and animals can 
127 migrate between areas with significant divergences in local ${ }^{87} \mathrm{Sr} /{ }^{86} \mathrm{Sr}$ values. If animals or 128 humans die and are interred in a location with a marked difference in local ${ }^{87} \mathrm{Sr} /{ }^{86} \mathrm{Sr}$ values from 129 their own biological tissues, they can be recognized as migrant individuals. This method for 130 identifying migrants has been used productively in many archaeological studies of human and 131 animal migration patterns (cf. Bentley, 2006; Crowley et. al, 2017; Price et al., 2002; Price et al., 132 2012).

134 Because using ${ }^{87} \mathrm{Sr} /{ }^{86} \mathrm{Sr}$ values to identify nonlocal humans and animals requires geologic 135 diversity over reasonably traversable distances, geologically homogeneous regions may limit this 136 method's effectiveness. Portugal and Western Spain exhibit marked differences in geological 137 lithologies, thereby making this region an excellent location to use strontium isotope 138 fingerprinting to study human and animal migration in prehistory. Nonetheless, we must keep in 139 mind that this methodology can only provide a minimum estimate of mobility (minimum number 140 of migrants, MNM), as it is not possible to distinguish between humans and animals who 141 originate from settlements that share similar bioavailable ${ }^{87} \mathrm{Sr} /{ }^{86} \mathrm{Sr}$ values due to similar 142 underlying geology. Additionally, it is important to note that this method assumes that local 143 populations only consumed local foods and drank from local water sources, as consumption of 144 large amounts of foreign foods can change ${ }^{87} \mathrm{Sr} /{ }^{86} \mathrm{Sr}$ values (Burton and Hahn, 2016).

\section{$146 \quad 2.1$ Archaeological sites and regional geology}

147 The prehistoric settlement sites of Leceia and Zambujal lie in the Estremadura region of Portugal 148 (Figure 1). The Estremadura is a historically-defined province in the southwestern region of 149 Portugal which encompasses both the Lisbon and Setúbal peninsulas and extends westward to 150 the Atlantic coast. Both Leceia and Zambujal lie close to the coast and to (former) estuaries and 151 interior waterways and, thus, would have been key places for both coastal and interior trade 152 networks.

$154 \quad$ 2.1.1 Zambujal

155 Zambujal is one of the most prominent and well-known prehistoric fortified settlements in 156 Portugal (Sangmeister and Schubart, 1981). It was occupied from the Chalcolithic period until 157 the early Bronze Age (c. 2900-1700 cal BC), and was subject to several important building 
158 phases with a series of walls and other fortifications (Arnold and Kunst, 2011; Kunst, 2010; 159 Kunst, 2018; Sangmeister and Schubart, 1981). Geomagnetic prospections, archaeological 160 surveys and excavations between 1994 and 2013 have indicated that the fortified settlement was 161 larger than previously thought, and is currently estimated at c. 26 hectares (Kunst and Uerpmann, 162 2002; Kunst et al. 2013; Kunst 2017a; Becker and Flade-Becker, 2017). Material culture 163 recovered from Zambujal suggests that it was permanently settled throughout the $3^{\text {rd }}$ millennium $164 \mathrm{BC}$ and that craft and metal production took place there, likely at a household scale (Müller et 165 al., 2007; Gauß, 2015; Kunst et al., 2016). Additionally, as evidenced by the recovery of raw 166 materials with origins outside of the region --such as copper, amphibolite, ivory and gold -

167 Zambujal was an important center of local and regional exchange networks, (Kunst, 1995; 168 Sangmeister and Schubart, 1981; Uerpmann, 1995; Uerpmann and Uerpmann, 2003).

By the end of the excavations that took place from 1964 to 1973, over 150,000 faunal specimens

171 had been recovered, representing over 95 species. Domestic cattle, pigs and caprines dominate, 172 but wild boar, aurochs and red deer are also present, albeit in comparatively small numbers (von 173 den Driesch and Boessneck, 1976; 1981). Caprines and pigs were the main focus of the domestic 174 assemblage, with smaller numbers of cattle.

\subsubsection{Leceia}

177 The fortified settlement of Leceia (c. 3500-2200 cal BC), had earlier origins than Zambujal, 178 during the late Neolithic period, but was also abandoned earlier - before the Early Bronze Age. 179 Excavations at the site between 1983 and 2002 revealed a complex settlement fortified by a 180 defensive series of stone walls and towers (Cardoso, 1994; 1997; 2000; 2010). Leceia has 181 received less attention than Zambujal, but its location (elevated above the river Barcarena), its 182 size, and its rich material culture, suggest it was an important regional center for agriculture, 183 material goods, production and trade (Cardoso, 2000). In contrast to Zambujal, there is poor 184 evidence for extractive metallurgy. Neither smelting slags or copper ore were found, but the 185 presence of many copper artefacts, including some which are unfinished, suggest that some 186 copper working was undertaken here (Müller and Cardoso, 2008). Other imported materials, 187 such as amphibolite, have also been recovered, indicating that the site was linked to broader exchange networks (Cardoso and Carvalhosa, 1995; Cardoso, 2004). Faunal remains recovered 
from Leceia were studied by Cardoso and Detry (2002), and were dominated by domestic cattle,

190 pigs and caprines throughout the period of occupation. Red deer represented the main wild 191 species but, unlike at Zambujal, no aurochs or wild boar were identified. Cattle, pigs and 192 caprines were present in equal proportions during the late Neolithic period but an increase in 193 caprines along with a decrease in cattle was seen during the Chalcolithic period, bringing the 194 overall proportions of these animals broadly in line with that seen at Zambujal. In contrast to 195 Zambujal no isotopic work on either human or faunal remains has previously been undertaken.

\subsubsection{Regional Geology}

198 The sites of Zambujal and Leceia both lie in the geologically diverse landscape of the 199 Estremadura region of Portugal (Figure 2). The area occupies a portion of the Lusitanian Basin, 200 which is a northern Atlantic basin that was created during a late Triassic rifting phase. In the 201 southeast, this basin connects to the Alentejo and the Algarve Basins and in the north and east it 202 abuts the Late Paleozoic Hercynian basement rocks of the Iberian Meseta (Cunha and dos Reis, 203 1995; Wilson, 1988). The Lusitanian Basin, mainly composed of Cretaceous and Jurassic 204 sediments with northern pockets of Triassic sediments, is geologically younger than other parts 205 of Portugal and Spain with a heterogeneous mix of lithologies including sandstones and 206 limestones, clays, marls, and some volcanic rocks (Azerêdo et al., 2002; Wilson, 1988: See 207 Waterman, 2012 for more detail). Because it is a carbonate-dominated Mesozoic landscape, 208 Lusitanian Basin sediments should have ${ }^{87} \mathrm{Sr} /{ }^{86} \mathrm{Sr}$ close to marine values (0.707-0.710: e.g. 209 Schneider et al., 2009). Additionally, as a coastal region, seawater rainfall and sea spray can be 210 incorporated into the terrestrial food chain which may also contribute to ${ }^{87} \mathrm{Sr} /{ }^{86} \mathrm{Sr}$ values that are 211 close to that of seawater (0.709) (Bentley, 2006). Slightly higher ${ }^{87} \mathrm{Sr} /{ }^{86} \mathrm{Sr}$ values should be found 212 in some parts due to variations in clastic deposits, and local water analyses have recorded $213{ }^{87} \mathrm{Sr} /{ }^{86} \mathrm{Sr}$ ratios of $0.709-0.711$ (Voerkelius et al., 2010). In contrast, the older Palaeozoic 214 Hercynian basement metamorphic and granitic rocks of the Portuguese interior should generally 215 have more radiogenic values $\left({ }^{87} \mathrm{Sr} /{ }^{86} \mathrm{Sr}>0.713\right.$ : e.g. Bea et al., 2003).

\section{3. Materials and Methods}

\section{$218 \quad 3.1$ Sampled materials}


219 For this study 16 cattle teeth from Leceia and 27 cattle teeth from Zambujal were analyzed.

220 (Table 1). The Leceia samples come from material that is housed in the Centro de Estudos 221 Arqueológicos do Concelho de Oeiras/Câmara Municipal de Oeiras (Bacarena, Portugal), 222 previously studied by Cardoso and Detry (2002). The Zambujal samples are from the von den 223 Driesch and Boessneck faunal assemblage which is currently housed at the Leonel Trindade 224 Municipal Museum (Torres Vedras, Portugal). The Zambujal samples selected are dominated by 225 specimens dated to the early Chalcolithic (c. 3000-2500 cal BC), whereas the majority of our 226 specimens from Leceia were dated to the Full/Late Chalcolithic (c. 2500-2200 cal BC).

228 Left third molars were prioritized to ensure that each sample was from a separate individual, and 229 one enamel slice per tooth was taken, in order to maximize the number of individuals being 230 investigated. A transversal slice of enamel was cut from the base of the protoconid using a 231 diamond cutter disc coupled to a dentist drill (following the method outlined in Minniti et al., 232 2014). Only fully formed teeth, with closed roots and which were in wear, were used. This made 233 the location independent from wear, and ensured that the samples were unaffected by any 234 potential age bias. Samples of both enamel and dentine were taken for 18 animals in order to 235 examine any intra-individual variation indicative of relationships between mobility and life 236 history. In order to test for potential effects of sample diagenesis 10 samples were divided during 237 the wet chemistry process and one portion underwent additional washes of acetic acid before 238 further processing.

\subsection{Determining Local Values}

241 The most established method for estimating the local ${ }^{87} \mathrm{Sr} /{ }^{86} \mathrm{Sr}$ range for a region is by using the 242 mean of sampled local faunal or human remains \pm 2 s.d. to account for the upper and lower limits 243 of the range. Because nonlocal outlier samples can skew the local estimate, tooth and bone 244 samples are best taken from animals with very limited geographic ranges (e.g. rabbits) (Bentley 245 et al., 2004; Price et al., 2002). Plants, water and soil samples can also provide local estimates, 246 but may not provide as accurate of an account of the local bioavailable range as animal tissues.

247 For this study local small fauna (rabbits) and plants were collected and analyzed to help 248 determine the local bioavailable ${ }^{87} \mathrm{Sr} /{ }^{86} \mathrm{Sr}$ isotope composition at Leceia and to reaffirm the local 249 range for Zambujal that was presented in Waterman et al., (2014). 


\subsection{Wet Chemistry and Mass Spectrometry}

252 All chemical processing of the samples was carried out at the University of Iowa Department of 253 Earth \& Environmental Sciences clean laboratory. Details of the laboratory protocol used for this 254 analysis followed the procedures outlined in Waight et al., (2002), see Waterman et al., (2014) 255 for a full description. ${ }^{87} \mathrm{Sr} /{ }^{86} \mathrm{Sr}$ ratios were measured using a $\mathrm{Nu}$ Plasma $\mathrm{HR}$ multicollector 256 inductively-coupled-plasma mass-spectrometer (MC-ICP-MS) in the Department of Geology at 257 the University of Illinois at Urbana-Champaign. Samples were introduced to the machine using a $258 \mathrm{Nu}$ Instruments DSN-100 desolvator system equipped with a nebulizer with an aspiration rate 259 near $0.1 \mathrm{~mL} \mathrm{~min}^{-1}$. The samples were alternately run with standards (SRM 987, SCS coral and 260 E\&A) using a sample-standard-bracketing measurement protocol wherein standards were run 261 every 3-5 samples (Rehkämper et al. 2004). The ${ }^{88} \mathrm{Sr}$ beam intensities for all samples and 262 standards ranged from 4 to $12 \mathrm{~V}$ (100 ppb solutions). Masses of ${ }^{83} \mathrm{Kr}$ to ${ }^{88} \mathrm{Sr}$ were measured 263 during a single cycle comprised of 2 blocks of 25 scans ( $5 \mathrm{~s}$ integration per scan) with a $40 \mathrm{~s}$ 264 baseline determination using ESA-deflected signals. Instrumental mass bias was internally 265 normalized to an ${ }^{86} \mathrm{Sr} /{ }^{88} \mathrm{Sr}$ ratio of 0.11940 and then corrected ratios were normalized to the 266 NIST SRM 987 international standard value of 0.710268 (which had a reproducibility of \pm 267 0.000013: 2 s.d., n=47) to correct for day-to-day variability. No corrections were necessary for 268 Sr introduced as part of sample production as procedural blanks were $<100 \mathrm{pg} \mathrm{Sr}$.

\section{Results}

271 Results are presented in Tables 1-2 and Figure 3. The 10 separated samples subjected to a more 272 rigorous regiment of acid washes showed negligible differences in $\mathrm{Sr}$ values to the control 273 samples (0.00019-0.00003), suggesting diagenesis was not a major concern for the dental 274 enamel. Both sites yielded results with a relatively wide range of enamel values. At Zambujal 275 enamel samples had an ${ }^{87} \mathrm{Sr} /{ }^{86} \mathrm{Sr}$ range of 0.7054 to 0.7127 , while at Leceia the range was wider, 276 from 0.7046 to 0.7179 . For Leceia, based upon the sampled leaves and small fauna, the local $277{ }^{87} \mathrm{Sr} /{ }^{86} \mathrm{Sr}$ value range is estimated to be $0.7067-0.7077$. For Zambujal the ${ }^{87} \mathrm{Sr} /{ }^{86} \mathrm{Sr}$ local range 278 was previously defined as 0.709-0.7115 (Waterman et al., 2014). The small fauna and leaves 279 tested in this analysis fell right below the lower end of this spectrum, thus we have adjusted the 280 local range for Zambujal slightly to $0.7085-0.7115$. This range fits the majority of the heavily 
clustered Zambujal fauna in this study. The dentine samples had a much smaller range than the

282 enamel at both sites. As dentine is more likely to be contaminated with the $\mathrm{Sr}$ isotope signature

283 from the local soil, or to remodel to the local $\mathrm{Sr}$ isotope signature after movement into a new

284 area, this more limited value range was expected. However, whilst at Zambujal all of the dentine

285 values fall within the calculated local range, at Leceia the dentine range is much wider and some

286 samples deviate from the calculated local range. This is an intriguing pattern which will be

287 discussed further below.

\subsection{Enamel values}

290 The cattle enamel samples from Zambujal and Leceia show some divergence in the ${ }^{87} \mathrm{Sr} /{ }^{86} \mathrm{Sr}$ 291 ratio with more specimens from each site clustering around the defined local ranges (Figure 3). 292 Using the nonparametric Mann-Whitney U test (due to the non-normal distribution of the data), 293 the differences between the sites are found to be extremely statistically significant $(\mathrm{p}=0.000)$ 294 (Table 3). These differences are also demonstrated using box plots in Figure 4. Density plots 295 (Figure 5) also show that cattle from Leceia display a wider range of values than Zambujal, 296 despite having a smaller sample size, indicating that Leceia had a wider catchment area for its 297 cattle.

299 At Zambujal a number of specimens plot outside of its local range. Those falling above are in the 300 range of 0.712-0.713, but those below are more spread out from 0.705-0.708. Some of these fall 301 within the local range calculated for Leceia (0.706-0.708), but one specimen falls even below 302 this range (0.705). At Leceia a number of specimens have values that are higher than the site's 303 local range. Most of these fall into the Zambujal range, but there is also one very high value 304 (0.7179), well above the local range calculated for either site. There are also some specimens that 305 fall in the region of the lowest values from Zambujal $(<0.705)$, lower than the range from either 306 site. These results highlight the possibility that cattle were being moved between these two sites, 307 but also that some of them must have been brought in from further afield.

\section{4.2 Dentine and enamel pairs}

310 For six cattle from Zambujal and three from Leceia both enamel and dentine were sampled from 311 the same animals (this was also attempted for four other individuals, but one sample failed in 
312 each case). These dentine and enamel sets were compared in order to look for evidence of

313 lifetime mobility (Table 2, Figure 6).

315 At Zambujal, all the cattle for which both dentine and enamel samples were taken exhibited very

316 low ${ }^{87} \mathrm{Sr} /{ }^{86} \mathrm{Sr}$ variation between samples (0.0001-0.0012). Additionally, all of these values fell

317 within the local range for Zambujal. None of these individuals, therefore, show clear evidence of

318 having been moved into Zambujal from outside of the region between the time of enamel

319 formation and dentine remodeling.

321 At Leceia two of the three sampled cattle exhibited relatively consistent enamel and dentine $\mathrm{Sr}$ 322 values. However, these values (on both the enamel and dentine) are all lower than the calculated 323 Leceia local range. For the third animal the enamel value was higher than local Leceia range 324 (0.7084) (close to the low-end of the Zambujal range), while the dentine value was below the 325 local Leceia range (0.7051) (similar in value from the first two cattle). This suggests that this 326 animal grew up in a different region from where it last lived. Additionally one other dentine 327 sample from Leceia (without an associated enamel sample due to machine error) exhibits a $\mathrm{Sr}$ 328 value which is fairly high (0.7122), matching some enamel samples from Zambujal. This is a 329 very high value to have been found in this area, and could potentially result from some kind of 330 contamination.

\section{5. Discussion}

333 The results from this study indicate that cattle were being moved into, out of, and within the 334 Estremadura region during the Chalcolithic period. This movement likely occurred most 335 commonly within the Estremadura region, and potentially between Leceia and Zambujal 336 themselves, which were two of the most prominent sites in the region. However, the data 337 gathered here suggests that some movement from more distant regions was also occurring. account for all the sampled cattle with the exception of the outlying sample from Leceia with a very high value of 0.7179 . These groups are: 
1. Cattle in the range of 0.7085-0.7115 that match local values for Zambujal and sites in the Zambujal region (from Waterman et al., 2014),

2. Cattle in the range of 0.706-0.708 that match local values from Leceia.

3. Cattle in the range of 0.712-0.713 which fall above the values for Zambujal.

4. Cattle in the range of $0.704-0.706$ which fall below local values for Leceia

In the Iberian Peninsula ${ }^{87} \mathrm{Sr} /{ }^{86} \mathrm{Sr}$ isotope ratio ranges are available for some geological areas based on water, soil, and plant data (e.g. Freitas et al., 2003; Moita et al., 2009; Schneider et al., 2009; Villaseca et al., 2009; Voerkelius et al., 2010), and predictions about likely ${ }^{87} \mathrm{Sr} /{ }^{86} \mathrm{Sr}$ isotope ratio ranges can be made for other areas based upon the local geologic lithologies. While detailed maps of bioavailable ${ }^{87} \mathrm{Sr} /{ }^{86} \mathrm{Sr}$ isotope ratios have not yet been completed for Portugal and Spain, a number of archaeological studies, focusing on individual archaeological sites or regions, have been completed in the last decade. These studies provide us with local bioavailable ${ }^{87} \mathrm{Sr} /{ }^{86} \mathrm{Sr}$ isotope range for a number of places in central and south-west Iberia that we can compare with the data from Zambujal and Leceia (Table 4, Figure 7). By examining these ranges, the diversity of local and regional geology, and the archaeological evidence for exchange networks in the region, we can begin to identify possible cattle origin and movement patterns in the Zambujal and Leceia regions.

Groups 1 and 2: These groups are composed of animals local to Zambujal and Leceia with ${ }^{87} \mathrm{Sr} /{ }^{86} \mathrm{Sr}$ isotope values of c. 0.707-0.712. These values are consistent with the underlying geology of most of the Estremadura region-mainly Mesozoic or Cenozoic sediments with small pockets of other lithologies. These are the most common types of underlying geology across Europe, and are present in many parts of Iberia. Local value ranges from most sites in the Estremadura region including Leceia and Zambujal (this study) the Zambujal region (Waterman et al., 2014), Bom Santo (Carvalho et al., 2016), and (part of the range of) Rego de Murta (Waterman et al., 2013) all fall into this range. These values are also present in some parts of the Alentejo region, such as at the site of Monte de Cegonha (Saragoça et al. 2016), as well as at a number of Spanish sites, including Valencina-Castilleja (Diaz-Zorita-Bonilla, 2013), and sites near Madrid (Díaz-del-Río et al., 2017). We are therefore unable to rule out the possibility that some of the sampled cattle in this group are, in fact, non-local but from a region with similar 
373 local ${ }^{87} \mathrm{Sr} /{ }^{86} \mathrm{Sr}$ isotope values. However, the most parsimonious approach to this dataset is to 374 assume these are animals raised locally and, as they are most numerous at both sites, that most cattle were raised and consumed locally during this time period.

377 Group 3: 'Non-local' animals with values between 0.712 and 0.713 . These are likely to be from an area with underlying Middle to Upper Palaeozoic sediments (Voerkelius et al., 2010). There are multiple areas in Iberia which have this kind of geology, including in southern Portugal in 380 both the eastern Alentejo and Algarve regions, but also in southern Spain as far away as Andalucia. In south-west Iberia the most prominent area with this kind of geology is the Ossa Morena Zone (OMZ) located in southern areas of Portugal and south-west Spain. The range of values here fits with those from La Pijotilla in south-west Spain, which is in this geological zone, but also at some sites near Madrid (Díaz-del-Río et al., 2017). However, in closer proximity the burial sites of Rego de Murta, located (170km) north and east of Zambujal have a calculated local ${ }^{87} \mathrm{Sr} /{ }^{86} \mathrm{Sr}$ isotope of $\sim 0.711-0.713$ (based on small fauna) but many humans and some larger fauna recovered from the burial had $\mathrm{Sr}$ isotope values in the 0.713-0.714 range. This suggests that this region could also be a place of origin for animals in the Group 2 category.

Group 4: 'Non-local' animals with values which fall below 0.707 . These are likely to be from an area with basaltic volcanic rocks such as the Quaternary and Tertiary volcanic rocks or in regions of basic Palaeozoic volcanic rocks. There are some small areas of the southern Estremadura which have the potential for yielding $\mathrm{Sr}$ isotope values this low. These are located to both the east and west of Leceia. No Sr isotope values are currently available from these areas, so these can only be considered as a possibility.

397 These groups and places of possible origin cover all of the cattle except the migrant animal with 398 the very high Sr isotope value at 0.7179 . This animal is likely to be from an area with underlying 399 Lower Palaeozoic sediments (Voerkelius et al., 2010). Some areas of the OMZ also have this 400 kind of geology, including parts of Alentejo. Perdigões, which is in this region has the highest 401 local values of any of the sites presented, with a local range of up to 0.7135-0.7145 (Žalaite et 402 al., 2018). However, the region around Perdigões has very varied geology, and as part of that study baseline samples were taken from a $10 \mathrm{~km}$ radius around the site in order to account for 
this. Some of the values that resulted from this were even higher -up to 0.7184 , which indicates that such high values are possible in this area. Waterman et al. (2014) found one human from the Cova da Moura burial near Zambujal to have a Sr isotope value even higher than the outlier animal (0.720), and the Waterman et al. (2013) study on humans from the Rego da Murta burials in the Ribatejo region of Portugal found three individuals who have $\mathrm{Sr}$ isotope values in the 0.717-0.720 range. This suggests that another potential place of origin may be from older geologic formations northeast of the Estremadura region.

The presence of raw materials and artefacts at Zambujal and Leceia provide more evidence of the links between the Estremadura and other regions. We know that variscite, slate, amphibolite, arsenical copper ore, and other materials from the Alentejo region (OMZ) commonly made their way into the Estremadura during the Chalcolithic period. Provenance studies based on lead isotope analysis of artefacts from both Zambujal and Leceia have also indicated that their raw materials come from ore deposits found in the OMZ (Gauß, 2013; Gauß, 2015; Müller and Cardoso, 2008). This increases the likelihood that at least some of the individuals from our result group 3 originate from this region.

Finally, some attention should be given to the differences in catchments between these two settlement sites, and why Leceia may have received livestock from a wider area than Zambujal. This is particularly interesting in the light of further isotopic work we have been undertaking in parallel to this study, which has indicated differences in cattle diet between the two sites (Wright et al., in prep). One possibility is that Leceia was geographically better located for contact with outside regions than Zambujal. It is located slightly closer to the Alentejo region, for example, and may have been a first point of contact for people travelling up into the Estremadura region from the south. Leceia is also located much closer to geology that could potentially yield low $\mathrm{Sr}$ isotope values, although this must remain a tentative suggestion until more Sr isotope mapping of the region is undertaken. A second option is that these patterns could be related to a temporal trend. As the sample from Leceia is dominated with specimens from Full/Late Chalcolithic layers, whereas the majority of the Zambujal sample is earlier in date. This could be reflecting an increase in cattle mobility through time during the Chalcolithic period, through increased use and 
434 consolidation of exchange networks in south-west Iberia. Larger datasets from more sites are 435 needed to be able to investigate this further.

437 An alternative explanation may be related to differences in husbandry practices between the two 438 settlements. Perhaps Zambujal was more effective at breeding and keeping its own herds than 439 Leceia was, so it had less need to incorporate more livestock from outside regions. This is 440 something that needs further investigation. The local environment surrounding each of these 441 settlements needs to be examined more closely in terms of suitability for cattle production, and 442 more detailed attention needs to be given to the differences in the faunal assemblages between 443 the two sites, tasks which are beyond the scope of this paper.

\section{6. Conclusion}

446 This paper provides the results of one of the first strontium isotope studies focusing on cattle 447 remains, animal mobility, and social organization in southern Portugal. Using data on cattle from 448 the expansive Portuguese Chalcolithic (3000/2900-2000 BC) settlement sites of Zambujal and 449 Leceia (Estremadura, Portugal), we provide evidence that cattle were circulating through the 450 region with non-local animals being documented at both sites. Results indicate that cattle at 451 Leceia had a wider catchment area for its stock than Zambujal, with more migrant animals. 452 Domesticated animals would have played an important role in these emerging economies of 453 these sites, and these exchange networks likely overlap with human mobility and the exchange of 454 other trade goods. Thus, these findings have important implications for our understanding of 455 long and short distant trade and regional economic integration. We suggest that it is likely that 456 cattle with non-local $\mathrm{Sr}$ values higher that the ${ }^{87} \mathrm{Sr} /{ }^{86} \mathrm{Sr}$ local range for Zambujal range may have 457 originated in the Ossa Morena Zone as other evidence of direct exchange links with prominent 458 sites in the Alentejo region, such as Perdigões, are documented. However, the origin for the 459 highest ${ }^{87} \mathrm{Sr} /{ }^{86} \mathrm{Sr}$ values (>0.718) are still being investigated. 
461 Future studies exploring the involvement of animals in exchange networks in Chalcolithic south462 west Iberia will require larger Sr datasets, alongside regionally focused zooarchaeological work 463 comparing animal husbandry regimes. While considerably more $\mathrm{Sr}$ isotope values are available 464 for prehistoric sites in south west Iberia than were just a few years ago, further research is needed 465 to provide regional baseline maps. To this end, the Australian National University/Griffith 466 University Strontium Basemap Project currently being undertaken by colleagues has great 467 potential for furthering our interpretation of this data set in the future.

\section{Acknowledgements}

470 This work was funded through an Archaeological Institute of America Archaeology in Portugal 471 Fellowship. Thanks to Silvia Valenzuela-Lamas for useful discussions on Iberian prehistoric 472 animal mobility, and to Mount Mercy Students Matthew Purl and Nicholas Wilson for their help 473 processing samples at the University of Iowa. Also thanks to Craig Lundstrom, Tom Johnson, 474 and Gideon Bartov of the University of Illinois at Urbana-Champaign for their help with the 475 Mass Spectrometry and to the Museu Municipal of Torres Vedras and the Centro de Estudos 476 Arqueológicos do Concelho de Oeiras/Câmara Municipal de Oeiras for allowing access to the 477 material included in this study. Finally, thank you to the two reviewers for their useful comments 478 and suggestions.

\section{References Cited}

481 Arnold, F., Kunst, M., 2011. Zur Rekonstruktion kupferzeitlicher Befestigungsanlagen auf der 482 Iberischen Halbinsel-Turm B von Zambujal (Torres Vedras, Lisboa, Portugal). Madrider 483 Mitteilungen 52, 36-86 and Farbtaf. 1 and Taf. 1-12. system. Sedimentology 49 (6), 1339-1370. 
489 Bea, F., Montero, P., Zinger, T., 2003. The nature, origin, and thermal influence of the granite 490 source layer of central Iberia. Journal of Geology 111, 579-595.

492 Beard, B.L., Johnson, C.M., 2000. Strontium isotope composition of skeletal material can 493 determine the birth place and geographic mobility of humans and animals. Journal of Forensic 494 Sciences 45, 1049-1061.

Becker, H., Flade-Becker, A.-S., 2017. Zambujal 2013, Teil 2. Magnetische Prospektionen. 497 Madrider Mitteilungen 58, 31-56.

Bentley, R.A., 2006. Strontium isotopes from the earth to the archaeological skeleton: A review. Journal of Archaeological Method and Theory 13, 135-187. https://doi.org/10.1007/s10816-006$5019009-\mathrm{x}$

Bentley, R.A., Price, T.D., Stephan, E., 2004. Determining the 'local' ${ }^{87} \mathrm{Sr} /{ }^{86} \mathrm{Sr}$ range for 504 archaeological skeletons: a case study from Neolithic Europe. Journal of Archaeological Science 505 31, 365-375. https://doi.org/10.1016/j.jas.2003.09.003

Burton, J.H., Hahn, R., 2016. Assessing the "local" ${ }^{87} \mathrm{Sr} /{ }^{86} \mathrm{Sr}$ ratio for humans. In: Grupe, G., 508 McGlynn, G.C., (Eds.) Isotopic Landscapes in Bioarchaeology. Springer, Berlin, Heidelberg. p113-121

511 Cabaço, N., 2010. Restos faunísticos emcontexto do Neolítico final do Sector Q do recinto dos

512 Perdigões (Reguengos de Monsaraz). Apontamentos de Arqueologia e Património 5, 27-30.

514 Cardoso, J.L., 1994. Leceia 1983-1993. Escavações do povoado pré-historico, Estudos 515 Arqueológicos de Oeiras no especial.

517 Cardoso, J.L., 1997. O povoado de Leceia sentinela do Tejo no terceiro milénio antes Cristo. 
520 Cardoso, J.L., 2000. The Fortified Site of Leceia (Oeiras) in the Context of the Chalcolithic in 521 Portuguese Estramadura. Oxford Journal of Archaeology 19(1), 37-55.

523 Cardoso, J.L., 2004. Polished stone artefacts at the prehistoric settlement of Leceia (Oeiras).

524 Madrider Mitteilungen. Mainz. 45: 1-32.

526 Cardoso, J.L., 2003. O comércio de matérias-primas de origem geológica dos meados do VI 527 milénio a.C. aos finais do III milénio a.C., no Ocidente peninsular: breve ensaio. Boletim da 528 Sociedade de Geografia de Lisboa 121, 91-106.

Cardoso, J.L., 2007. Pré-História de Portugal. Universidade Aberta, Lisboa.

532 Cardoso, J.L., 2010. Povoado pré-histórico de Leceia (Oeiras): evolução arquitectónica do 533 sistema defensivo e das técnicas construtivas correlativas. Transformação e Mudança no centro 534 e sul de Portugal: o 4. ${ }^{\circ}$ e o 3. ${ }^{\circ}$ milénios a.n.e. Colóquio Internacional (Cascais, 2005). Actas 4353563.

537 Cardoso, J.L., Carvalhosa, A.B., 1995. Estudos petrográficos de artefactos de pedra polida do 538 povoado pré-histórico de Leceia (Oeiras). Análise de proveniências. Estudos Arqueológicos de 539 Oeiras 5, 123-151.

541 Cardoso, J.L, Detry, C., 2002. Estudo Arqueozoológico Dos Restos de Ungulados Do Povoado 542 Préhistórico de Leceia (Oeiras). Estudos Arqueológicos de Oeiras 10, 131-82.

544 Cardoso, J., Schuhmacher, T.X., 2012. Marfiles calcolíticos en Portugal. Estado de la cuestión. 545 Elfenbeinstudien. Marfil y elefantes en la Península Ibérica y el Mediterrâneo occidental. Actas 546 del coloquio internacional en Alicante el 26 y 27 noviembre 2008. Darmstadt/Mainz :Verlag 547 Philipp von Zabern, 95-110 (Iberia Archaeologica Band 16 Faszikel 1). 
549 Cardoso, J.L., Vilstrup, J.T., Eisenmann, V., Orlando, L., 2013. First evidence of Equus asinus

550 L. in the Chalcolithic disputes the Phoenicians as the first to introduce donkeys into the Iberian

551 Peninsula. Journal of Archaeological Science 40, 4483-4490.

552 https://doi.org/10.1016/j.jas.2013.07.010

554 Carvalho, A.F., Alves-Cardoso, F., Gonçalves, D., Granja, R., Cardoso, J.L., Dean, R.M., Gibaja, 555 J.F., Masucci, M.A., Arroyo-Pardo, E., Fernández-Domínguez, E., Petchey, F., Douglas Price, 556 T., Mateus, J.E., Queiroz, P.F., Callapez, P., Pimenta, C., Regala, F.T., 2016. The Bom Santo 557 Cave (Lisbon, Portugal): Catchment, Diet, and Patterns of Mobility of a Middle Neolithic 558 Population. European Journal of Archaeology 19, 187-214. 559 https://doi.org/10.1179/1461957115Y.0000000014.

Correia, F., 2015. O Castro da Columbeira (Bombarral): A Exploração dos Recursos Faunísticos no Calcolítico Estremenho (Masters Thesis). Universidade do Algarve.

Crowley, B.E., Miller, J.H., Bataille, C.P., 2017. Strontium isotopes (87Sr/86Sr) in terrestrial ecological and palaeoecological research: empirical efforts and recent advances in continentalscale models. Biological Reviews 92(1), 43-59.

Cunha P.P, dos Reis R.P., 1995. Cretaceous sedimentary and tectonic evolution of the northern sector of the Lusitanian Basin (Portugal). Cretaceous Research 16, 155-170.

Davis, S., Mataloto, R., 2012. Animal Remains from Chalcolithic São Pedro (Redondo, 572 Alentejo): Evidence for a Crisis in the Mesolithic. Revista Portuguesa de Arqueologia 15, 47-85.

574 Díaz-del-Río, P., Waterman, A.J., Thomas, J.T., Peate, D.W., Tykot, R.H., Martínez-Navarrete, 575 M.I., Vicent, J.M., 2017. Diet and mobility patterns in the Late Prehistory of central Iberia $576(4000-1400 \mathrm{cal} \mathrm{BC})$ : the evidence of radiogenic $\left({ }^{87} \mathrm{Sr} /{ }^{86} \mathrm{Sr}\right)$ and stable $\left(\delta^{18} \mathrm{O}, \delta^{13} \mathrm{C}\right)$ isotope ratios. 577 Archaeological and Anthropological Sciences 9, 1439-1452. https://doi.org/10.1007/s12520$578 \quad \underline{017-0480-y}$ 
Diaz-Zorita-Bonilla, M. 2013. The Copper Age in South-West Spain: A Bioarchaeological approach to prehistoric social organisation. PhD Thesis. Durham University

Díaz-Zorita Bonilla, M., 2013. Bioarqueología de las prácticas funerarias del yacimiento de la 584 Edad del Cobre de Valencina de la Concepción-Castilleja de Guzmán: revisión de las investigaciones (State of the art of the bioarchaeology of the funerary practices at the archaeological site of Valencina de la Concepción). In: García Sanjuán, L., Hurtado Pérez, V., Vargas Jiménez, J. M., Ruiz Moreno, T. and Cruz-Auñón Briones, R. (Eds): Valencina Prehistórica. Actas del Congreso Conmemorativo del Descubrimiento de La Pastora (18602010). Sevilla, Universidad de Sevilla.

Díaz-Zorita Bonilla, M., Beck, J., Bocherens, H., Díaz-del-Río, P., 2018. Isotopic evidence for mobility at large-scale human aggregations in Copper Age Iberia: the mega-site of Marroquíes. Antiquity, 92(364), 991-1007.

Driesch, von den, A., Boessneck, J., 1976. Die Fauna vom Castro do Zambujal (Fundmaterial der Grabungen von 1966 bis 1973 mit Ausnahme der Zwingerfunde). In: Studien über frühe 597 Tierknochenfunde von der Iberischen Halbinsel 5. München, Madrid: Institut für 598 Palaeoanatomie, Domestikationsforschung und Geschichte der Tiermedizin der Universität 599 München. Deutsches Archäologisches Institut Abteilung Madrid.

601 Driesch, von den, A., Boessneck J., 1981. Die fauna von Zambujal. In: Sangmeister E, Schubart 602 H, (Eds). Zambujal, die grabungen 1964 bis 1973. Mainz am Rhein: P. Von Zabern. p302-314.

604 Ericson J.E., 1985. Strontium isotope characterization in the study of prehistoric human ecology. 605 Journal of Human Evolution 14(5), 503-514.

607 Faure G, Powell J.L., 1972. Strontium isotope geology. New York, N.Y: Springer-Verlag. 608

609 Freitas, M.C., Andrade, C., Rocha, F., Tassinari, C., Munha, J.M., Cruces, A., Vidinha, J., da 610 Silva, C.M., 2003. Lateglacial and Holocene environmental changes in Portuguese coastal 
611 lagoons 1: the sedimentological and geochemical records of the Santo André coastal area. 612 Holocene 13, 433-446.

614 Gauß, R., 2013. The development of metallurgy on the Iberian Peninsula. Technological and 615 social patterns of a long-term innovation process. In: Burmeister, S., Hansen, S., Kunst, M., 616 Müller-Scheeßel, N. (Eds.), Metal Matters: Innovative Technologies and Social Change in 617 Prehistory and Antiquity, Menschen-Kulturen-Traditionen, Studien aus den Forschungsclustern 618 des Deutschen Archäologischen Instituts 12, Rahden/Westf.:Marie Leidorf, p209-229.

Gauß, R., 2015. Zambujal und die Anfänge der Metallurgie in der Estremadura (Portugal).

621 Technologie der Kupfergewinnung, Herkunft des Metalls und soziokulturelle Bedeutung der 622 Innovation. Iberia Archaeologica 15, 1. Ernst Wasmuth Verlag, Tübingen, Berlin.

624 Gilli, A., Hodell, D.A., Kamenov, G.D., Brenner, M., 2009. Geological and archaeological 625 implications of strontium isotope analysis of exposed bedrock in the Chicxulub crater basin, 626 northwestern Yucatan, Mexico. Geology 37(8), 723-726.

628 Gonçalves, V.S., 2000/2001. O Trigo, a Cobre, a Lã e o Leite: Um Guia Bibliográfico e Uma 629 Curta Introdução Às Sociedades Camponesas Da Primeira Metade Do $3^{\circ}$ Milénio No Centro e 630 Sul de Portugal. Zephyrus 53-54, 273-92.

632 Goncalves, V.S., Sousa, A.C., Costeira, C., 2013. Walls, gates and towers. Fortified settlements 633 in the south and centre of Portugal: some notes about violence and walls in the 3rd millenium 634 BCe. Cuadernos de Prehistoria y Arqueologia de la Universidad de Granada 23, 35-97.

636 Graustein, W.C., 1989. ${ }^{87} \mathrm{Sr} /{ }^{86} \mathrm{Sr}$ ratios measure the sources and flow of strontium in terrestrial 637 ecosystems. In: Rundel, P, Ehleringer, J.R., Nagy, K.A. (Eds.) Stable isotopes in ecological research Springer, New York. p491-512.

640 Harrison, R. J. 1985., The "Policultivo Ganadero," or the Secondary Products Revolution in 641 Spanish Agriculture, 5000-1000 BC. Proceedings of the Prehistoric Society 51, 75-102. 
643 Jorge, S.O. 2000, Domesticating the Land: The First Agricultural Communities in Portugal. 644 Journal of Iberian Archaeology 2, 43-98.

646 Knudson, K.J., Stanish, C., Cerna, M.C.L., Faull, K.F., Tantaleán, H., 2016. Intra-individual 647 variability and strontium isotope measurements: A methodological study using ${ }^{87} \mathrm{Sr} /{ }^{86} \mathrm{Sr}$ data 648 from Pampa de los Gentiles, Chincha Valley, Peru. Journal of Archaeological Science: Reports $6495,590-597$.

Kunst, M., 1995. Central Places and Social Complexity in the Iberian Copper Age. In: Lillios, K.T. (Eds.) The Origins of Complex Societies in Late Prehistoric Iberia. International Monographs in Prehistory Ann Arbor. p32-43.

Kunst, M., 2010. Zambujal, A dinâmica da sequência construtiva. In: Gonçalves, V.S., Sousa, A.C. (Eds.) Transformação e Mudança no Centro e Sul de Portugal: o 4. ${ }^{\circ}$ e o3. milénios a.n.e., Actas do Colóquio Internacional (Cascais, 4-7 Outubro 2005), Colecção Cascais Tempos Antigos 2, Cascais, 131-153.

Kunst, M., Morán, E., Parreira, R., 2013. Zambujal (Torres Vedras, Lisboa): relatório das escavações de 2002. Revista Portuguesa de Arqueologia 16, 103-131.

663 Kunst, M., 2017a. Zambujal 2013, Teil 1. Eine kupferzeitliche befestigte Groß-Siedlung? 664 Vermessungsarbeiten und Prospektionen, mit einem Anhang von Anika Herb, Madrider 665 Mitteilungen 58, 1-30

667 Kunst, M., 2017b. Campaniforme em Zambujal (Torres Vedras). In: Gonçalves, V.S. (Ed.) Sinos 668 e Taças junto ao Oceano e mais longe. Aspectos da presença campaniforme na Península Ibérica, 669 Bells and bowls near the ocean and far away. About beakers in the Iberian Peninsula, Estudos \& 670 memórias 10, UNIARQ, Lisboa, 194-213. 
672 Kunst, M., Dambeck, R., Thiemeyer, H., 2016. Climatic and Environmental Changes on the 673 Iberian Peninsula: The Sizandro and Alcabrichel Project and some Considerations on 674 Neolithisation and the Beginning of the Bell-Beaker Phenomenon. In: Reindel, M., Bartl, K., 675 Lüth, F., Benecke, N. (Eds.), Palaeoenvironment and the Development of Early Settlements. 676 Proceedings of the International Conferences Palaeoenvironment and the Development of Early 677 Societies (Şanlıurfa/Turkey, 5-7 October 2012), The Development of Early Settlement in Arid 678 Regions (Aqaba/Jordan, 12-15 November 2013), Menschen-Kulturen-Traditionen. Studien aus 679 den Forschungsclustern des Deutschen Archäologischen Instituts 14, Rahden/Westfalen: Marie 680 Leidorf, p51-62.

682 Kunst, M., Uerpamm, H.-P., 2002. Zambujal (Torres Vedras, Lisboa): relatório das escavações 683 de 1994 e 1995, Revista Portuguesa de Arqueologia 5 (1), 67-120.

Lillios, K.T., 1995. The Origins of Complex Societies in Late Prehistoric Iberia. International Monographs in Prehistory, Ann Arbor.

Lillios, K.T., 1997. Amphibolite Tools of the Portuguese Copper Age (3000-2000 BC): A 690 Geoarchaeological Approach to Prehistoric Economics and Symbolism. Geoarchaeology 12(2), 691 137-163.

693 Madgwick, R., Lewis, J., Grimes, V., Guest, P., 2017. On the hoof: exploring the supply of 694 animals to the Roman legionary fortress at Caerleon using strontium $\left({ }^{87} \mathrm{Sr} /{ }^{86} \mathrm{Sr}\right)$ isotope analysis. 695 Archaeological and Anthropological Sciences 11(1), 223-225.

697 Minniti, C., Valenzuela-Lamas, S., Evans, J., Albarella, U., 2014. Widening the market. 698 Strontium isotope analysis on cattle teeth from Owslebury (Hampshire, UK) highlights changes 699 in livestock supply between the Iron Age and the Roman period. Journal of Archaeological 700 Science 42, 305-314. https://doi.org/10.1016/j.jas.2013.10.008

702 Moita, P., Santos J.F., Pereira M.F., 2009. Layered granitoids: Interaction between continental 
703

crust recycling processes and mantle-derived magmatism. Examples from the Évora Massif (Ossa Morena Zone, southwest Iberia, Portugal). Lithos 111, 125-141.

Moreno-García, M., Sousa, A.C., 2013. A exploração de recursos Final, faunísticos no Penedo do Lexim (Mafra) durante no Neolítico Final. In: Gonçalves, V.S., Diniz, M., Sousa, A.C. (Eds.) $5^{\circ}$ Congresso do Neolítico Peninsular. Cascais: Câmara Municipal de Cascais, p67-76.

Müller, R., Cardoso, J., 2008. The origin and use of copper at the Chalcolithic fortification of Leceia, Portugal. Madrider Mitteilungen 49, 64-93.

Müller, R., Goldenberg, G., Bartelheim M., Kunst, M., Pernicka, E., 2007. Zambujal and the beginnings of metallurgy in southern Portugal. In: La Niece, S., Hook, D., Craddock, P (Eds). Metals and mines studies in Archaeometallurgy. London: Archetype. p15-26.

Nelson B.K., DeNiro, M.J., Schoeninger M.J., DePaolo D.J., Hare, P.E., 1986. Effects of diagenesis on strontium, carbon, nitrogen, and oxygen concentration and isotopic composition in bone. Geochim Cosmochim 50, 1941-1949.

Odriozola, C.P., Linares-Catela, J.A., Hurtado-Pérez. V., 2010. Variscite Source and Source Analysis: Testing Assumptions at Pico Centeno (Encinasola, Spain). Journal of Archaeological Science 37(12), 3146-3157. https://doi.org/10.1016/j.jas.2010.07.016.

Odriozola, C., Villalobos García, R., Boaventura, R., Sousa, A.C., Martínez-Blanes, J. M., 2013. Las producciones de adorno personal en rocas verdes del SW peninsular: los casos de Leceia, Moita da ladra y Penha Verde. Estudos Arqueológicos de Oeiras 20, 605-622.

Price, T.D., Burton, J.H., Bentley, R.A., 2002. The characterization of biologically available strontium isotope ratios for the study of prehistoric migration. Archaeometry 44, 117-135.

Price, T.D., Burton, J., Cucina, A, Zabala, P., Frei, R., Tykot, R.H., Tiesler, V., 2012. Isotopic studies of human skeletal remains from a Sixteenth to Seventeenth Century AD churchyard in Campeche, Mexico: diet, place of origin, and age. Current Anthropology 53(4), 396-433. 
735 Price, T.D., Burton, J.H., Fullagar, P. D., Wright, L. E., Buikstra, J. E., Tiesler, V., 2015.

736 Strontium isotopes and the study of human mobility among the Ancient Maya. In: Cucina, A 737 (Ed): Archaeology and bioarchaeology of population movement among the Prehispanic Maya. 738 Springer, Cham. p119-132.

740 Rehkämper, M., Wombacher, F., Aggarwal, J.K., 2004. Stable isotope analysis by. Multiple 741 Collector ICP-MS. In: de Groot, P.A. (Ed.), Handbook of Stable Isotope Analytical Techniques. 742 Elsevier, p692-725.

744 Roberts, B., 2008. Migration, Craft Expertise and Metallurgy: Archaeological Review from 745 Cambridge 23(2), 27-45.

747 Sangmeister, E., Schubart, H. 1981. Zambujal, Die Grabungen 1964 bis 1973. Madrider Beiträge 748 5,1. Mainz: Philipp von Zabern.

750 Saragoça, P., Maurer, A.-F., Šoberl, L., Lopes, M. da C., Alfenim, R., Leandro, I., Umbelino, C., 751 Fernandes, T., Valente, M.J., Ribeiro, S., Santos, J.F., Janeiro, A.I., Barrocas, C.D., 2016. Stable 752 isotope and multi-analytical investigation of Monte da Cegonha: A Late Antiquity population in 753 southern Portugal. Journal of Archaeological Science: Reports 9, 728-742.

755 Sealy, J.C., van der Merwe, N.J., Sillen, A., Kruger, F.J., Krueger, H.W., 1991. ${ }^{87} \mathrm{Sr} /{ }^{86} \mathrm{Sr}$ as a 756 Dietary Indicator in Modern and Archaeological Bone. Journal of Archaeological Science 18, $757 \quad 399-416$.

759 Schneider, S., Fürsich, F.T., Werner, W., 2009. Sr-isotope stratigraphy of the Upper Jurassic of 760 central Portugal (Lusitanian Basin) based on oyster shells. International Journal of Earth 761 Sciences. 98(8), 1949-1970.

763 Schroeder H.A., Nason A.P., Tipton I.H., 1972. Essential metals in man: strontium and barium. 764 Journal of Chronic Diseases 25, 491-517. 
766 Schuhmacher, T.X., 2012. Die Elfenbeinobjekte des Chalkolithikums und der Frühen Bronzezeit 767 auf der Iberischen Halbinsel. Interdisziplinäre Studien zu Herkunft, Austausch, Verarbeitung und 768 sozialer Bedeutung von Elfenbein. Iberia Archaeologica 16(2). Darmstadt, Mainz: Philipp von 769 Zabern.

771 Schuhmacher, T.X., 2017. Ivory Exchange Networks in the Chalcolithic of the Western 772 Mediterranean. In: Bartelheim, M., Bueno Ramírez, P., Kunst, M. (Eds.), Key Resources and 773 Socio-Cultural Developments in the Iberian Chalcolithic, RessourcenKulturen 6, Tübingen, $774 \mathrm{p} 291-312$.

775

776 Schuhmacher, T.X., Cardoso, J.L., Banerjee, A., 2009. Sourcing African ivory in Chalcolithic 777 Portugal. Antiquity 83: 983-997.

Tommasini S., Tesciona, I., Casalini, M., Braschi, E., Avanzinelli, R., Conticelli, S., 2018 780 Strontium Isotopes in Biological Material: A Key Tool for the Geographic Traceability of Foods 781 and Humans Beings. In: Gupta D., Walther C. (Eds.) Behaviour of Strontium in Plants and the 782 Environment. Springer, Cham. p145-166

783

784 Uerpmann, H.-P., 1995. Observações sobre a ecologia e economia do Castro do Zambujal. In: 785 Kunst, M. (Ed.), Origens, Estruturas e Relações das Culturas Calcolíticas da Península Ibérica, 786 Actas das I Jornadas Arqueológicas de Torres Vedras 3-5 Abril 1987, Trabalhos de Arqueologia 787 7, Lisboa: IPPA, p47-53.

789 Uerpmann, H-P., Uerpmann, M., 2003. Zambujal: Die Stein und Beinartefakte aus den 790 Grabungen 1964 bis 1973. Madrider Beiträge Band 5, Zambujal Teil 4. Mainz am Rhein: Philip 791 von Zabern.

792

793 Valente, M.J. 2013. Moinho de Valadares, Mourão. Estudo da fauna mamalógica das sondagens 794 1, 2 e 3 (Campanha de 1999). In: Valera, A.C. (Ed.), As sociedades agropastoris na margem 795 esquerda do Guadiana (2 a metade do IV aos inícios do II milénio AC). EDIA/DRCALEN. 
p353-360.

Valente, M.J., Carvalho, A.F., 2014. Zooarchaeology in the Neolithic and Chalcolithic of Southern Portugal. Environmental Archaeology 19(3), 226-240.

Valera, A.C., Simão, I., Nunes, T., do Pereiro, T., Costa, C., 2017. Neolithic ditched enclosures in Southern Portugal (4th millennium BC): New data and new perspectives. Estudos do 803 Quaternário/Quaternary Studies 17, 57-76.

Villaseca, C., Bellido, F., Pérez-Soba, C., Billström, K., 2009. Multiple crustal sources for posttectonic I type granites in the Hercynian Iberian Belt. Mineralogy and Petrology 96, 197-211.

Voerkelius, S., Lorenz Gesine, D., Rummel, S., Quétel Christophe, R., Heiss, G., Baxter, M.,

Brach-Papa, C., Deters-Itzelsberger, P., Hoelzl, S., Hoogewerff, J., Ponzevera, E., Van

810 Bocxstaele, M., Ueckermann, H., 2010. Strontium isotopic signatures of natural mineral waters,

811 the reference to a simple geological map and its potential for authentication of food. Food

812 Chemistry 118, 933-940. https://doi.org/10.1016/j.foodchem.2009.04.125.

814 Waight, T.E., Baker, J.A., Peate, D.W., 2002. Sr isotope ratio measurements by double focusing 815 MC-ICPMS: techniques, observations and pitfalls. International Journal of Mass Spectrometry $816221,229-244$.

818 Waterman, A.J. 2012. Marked in Life and Death: Identifying biological markers of social 819 differentiation in late prehistoric Portugal. PhD Thesis. University of Iowa.

821 Waterman, A., Figueiredo, A., Thomas, J., Peate, D., 2013. Identifying migrants in the late 822 Neolithic burials of the antas of Rego da Murta (Alvaiazere, Portugal) using strontium isotopes. 823 Antrope 0, 190-196.

825 Waterman, A.J., Peate, D. W., Silva, A.M, Thomas, J.T., 2014. In Search of Homelands: Using 826 Strontium Isotopes to Identify Biological Markers of Mobility in Late Prehistoric Portugal. 
Journal of Archaeological Science 42, 119-27. https://doi.org/10.1016/j.jas.2013.11.004.

829 Wilson, R.C.L., 1988. Mesozoic development of the Lusitanian Basin, Portugal. Revista de la 830 Sociedad Geológica de España 1, 393-407.

832 Žalaite, I., Maurer, A.F., Grimes, V., Silva, A.M., Ribeiro, S., Santos, J.F., Barrocas Dias, C., 833 Valera, A.C., 2018. Diet and mobility of fauna from Late Neolithic-Chalcolithic site of 834 Perdigões, Portugal. Journal of Archaeological Science: Reports 19, 674-685. 835 https://doi.org/10.1016/j.jasrep.2018.03.033

837 Zhao, C. 2015. Strontium isotope analysis and human mobility from late Neolithic to early 838 Bronze Age in the central plain of China. CAA2015, 783.

\section{List of Tables}

841 Table $1:{ }^{87} \mathrm{Sr} /{ }^{86} \mathrm{Sr}$ results from all samples

\section{Table 2: Results from enamel and dentine pairs}

845 Table 3: Results of the Mann-Whitney U test for differences in ${ }^{87} \mathrm{Sr} /{ }^{86} \mathrm{Sr}$ values between sites

Table 4: ${ }^{87} \mathrm{Sr} /{ }^{86} \mathrm{Sr}$ generalized `local` values from other sites across central and south west Iberia

\section{List of Figures}

850 Figure 1: Location of the two sites

852 Figure 2: Geological map of the study area

854 Figure 3: Plot of ${ }^{87} \mathrm{Sr} /{ }^{86} \mathrm{Sr}$ ratios from cattle teeth at Zambujal and Leceia, alongside ratios taken from 855 locally collected rabbit and plants. The generalised local range for Zambujal is shown in green, and for 856 Leceia in blue.

858 Figure 4: Box-plot comparing ${ }^{87} \mathrm{Sr} /{ }^{86} \mathrm{Sr}$ enamel values between the two sites 
860 Figure 5: Density plots comparing ${ }^{87} \mathrm{Sr} /{ }^{86} \mathrm{Sr}$ enamel values between the two sites

861

862 Figure 6: Plot showing ${ }^{87} \mathrm{Sr} /{ }^{86} \mathrm{Sr}$ values for enamel and dentine pairs

863

864 Figure 7: Sites listed in table with generalized ${ }^{87} \mathrm{Sr} /{ }^{86} \mathrm{Sr}$ ranges. 1. Leceia, 2. Zambujal, 3. Bom Santo, 4.

865 Perdigões, 5. La Pijotilla, 6. Rego da Murta I and II, 7. Valencina de la conception, 8. Madrid-region

866 sites. 9. Monte da Cegonha 


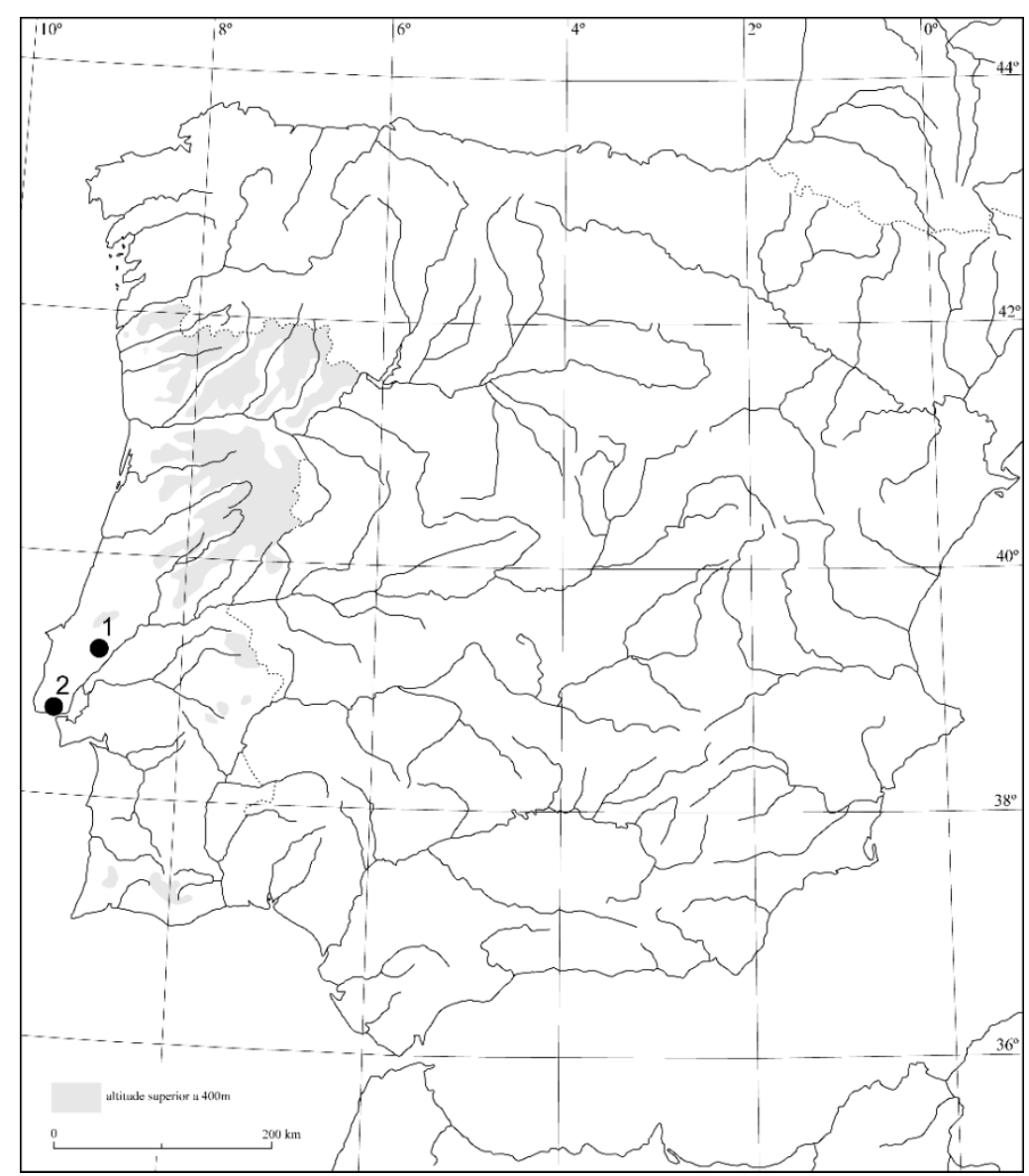

Figure 1: Location of the two sites. 1: Castro do Zambujal; 2. Leceia 


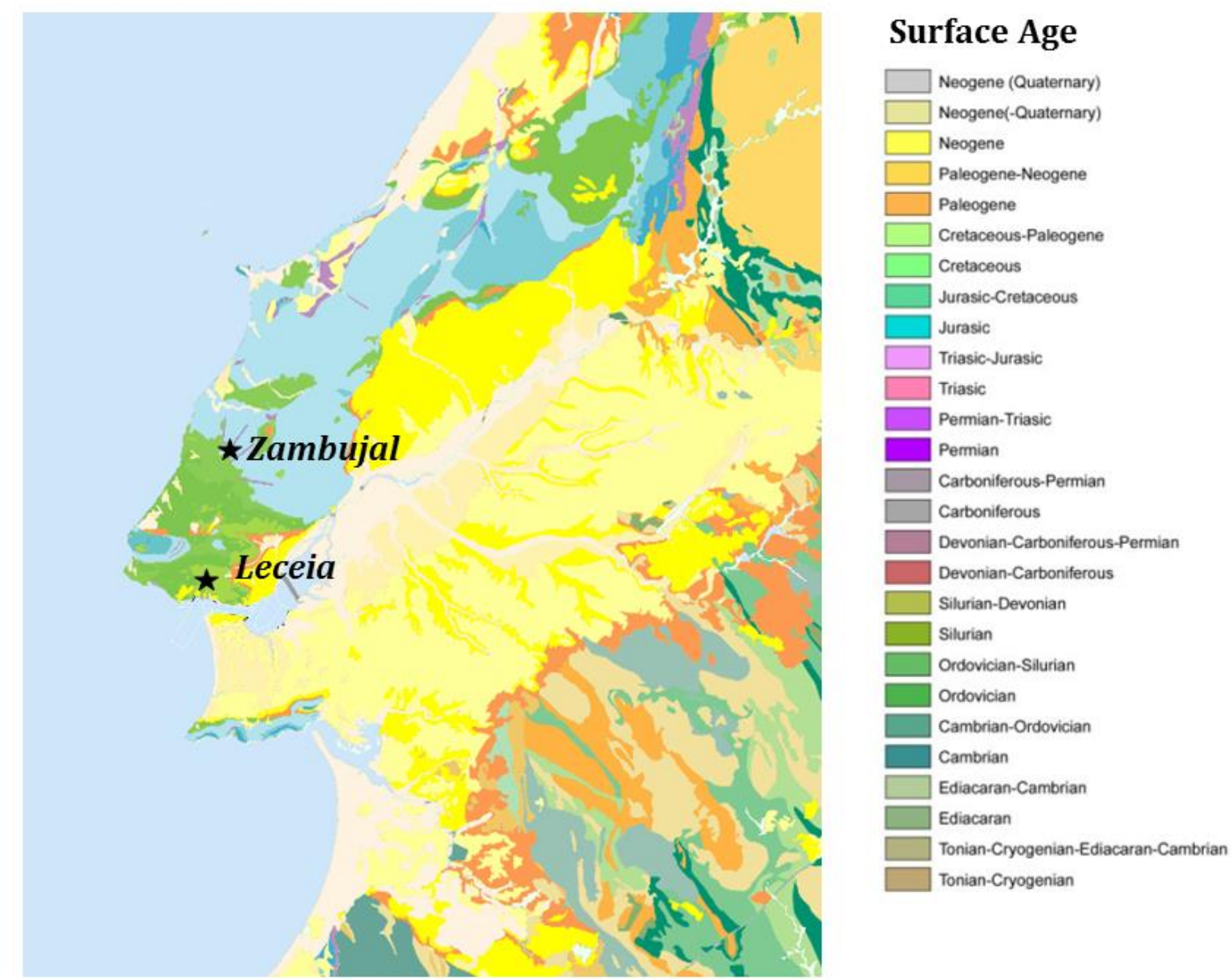

\section{Surface Lithology}

Gravel, conglomerate, sand and silt

Conglomerate, sandstone, slate and limestone. Evaporites

Conglomerate, sandstone and siltstone

Conglomerate, sandstone, limestone. gypsum and variegated mudstone

Conglomerate, sandstone, slate and limestone. Coal

Sandstone, conglomerate, slate and limestone. Evaporites

Sandstone, slate and limestone

Detritic limestone, calcarenite, mart, shale and limestone

Limestone, dolostone and marl. Sandstone and conglometare

Dolostone, limestone and mart. Sandstone
Quartzite, slate, sandstone and limestone

Slate, graywacke, quartzite and conglomerate

Mica-schist, phyllite, sandstone, marble, limestone, dolostone and marl

Gneisses

Migmatite, marble and undifferentiated granitoids

Volcanic and volcaniclastic rocks

Other granitoids

Two-mica granitoid

Serpentinite and peridotite. Basic and ultrabasic rocks

Figure 2: Geological map of the study area 


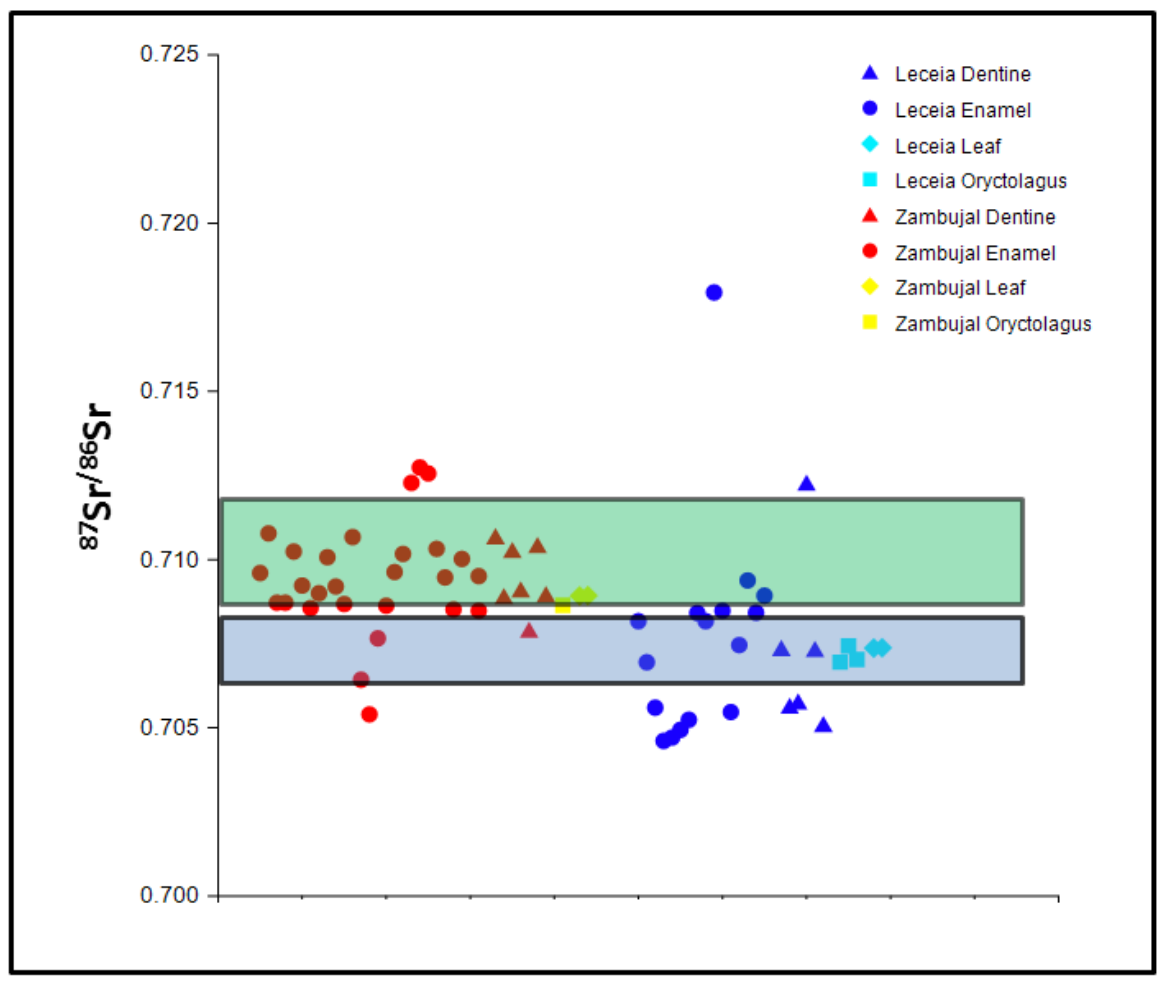

Figure 3: Plot of ${ }^{87} \mathrm{Sr} /{ }^{86} \mathrm{Sr}$ ratios from cattle teeth (enamel and dentine) at Zambujal and Leceia, alongside ratios taken from locally collected rabbit and plants. The generalised local range for Zambujal is shown in green, and for Leceia in blue. 


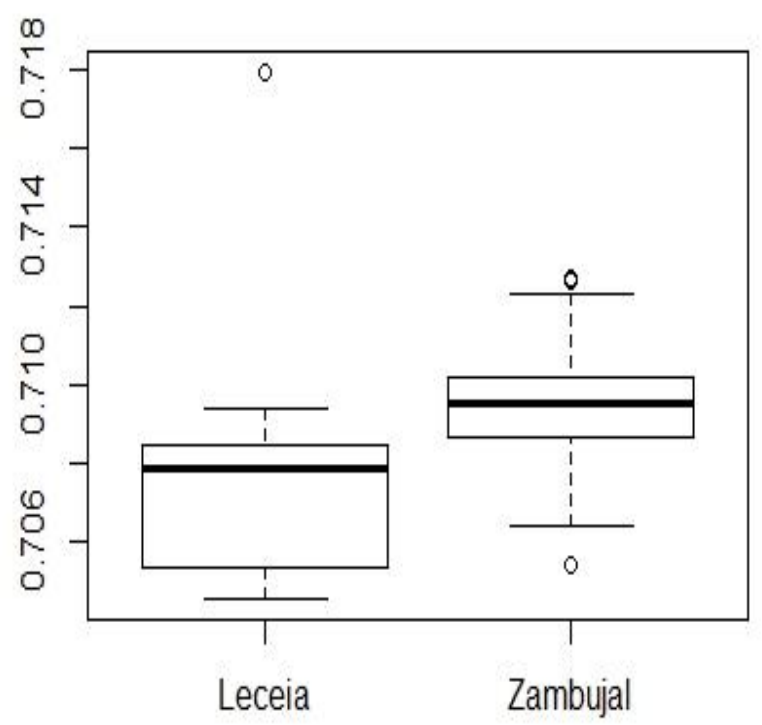

Figure 4: Box-plot comparing ${ }^{86} \mathrm{Sr} /{ }^{87} \mathrm{Sr}$ enamel values between the two sites 

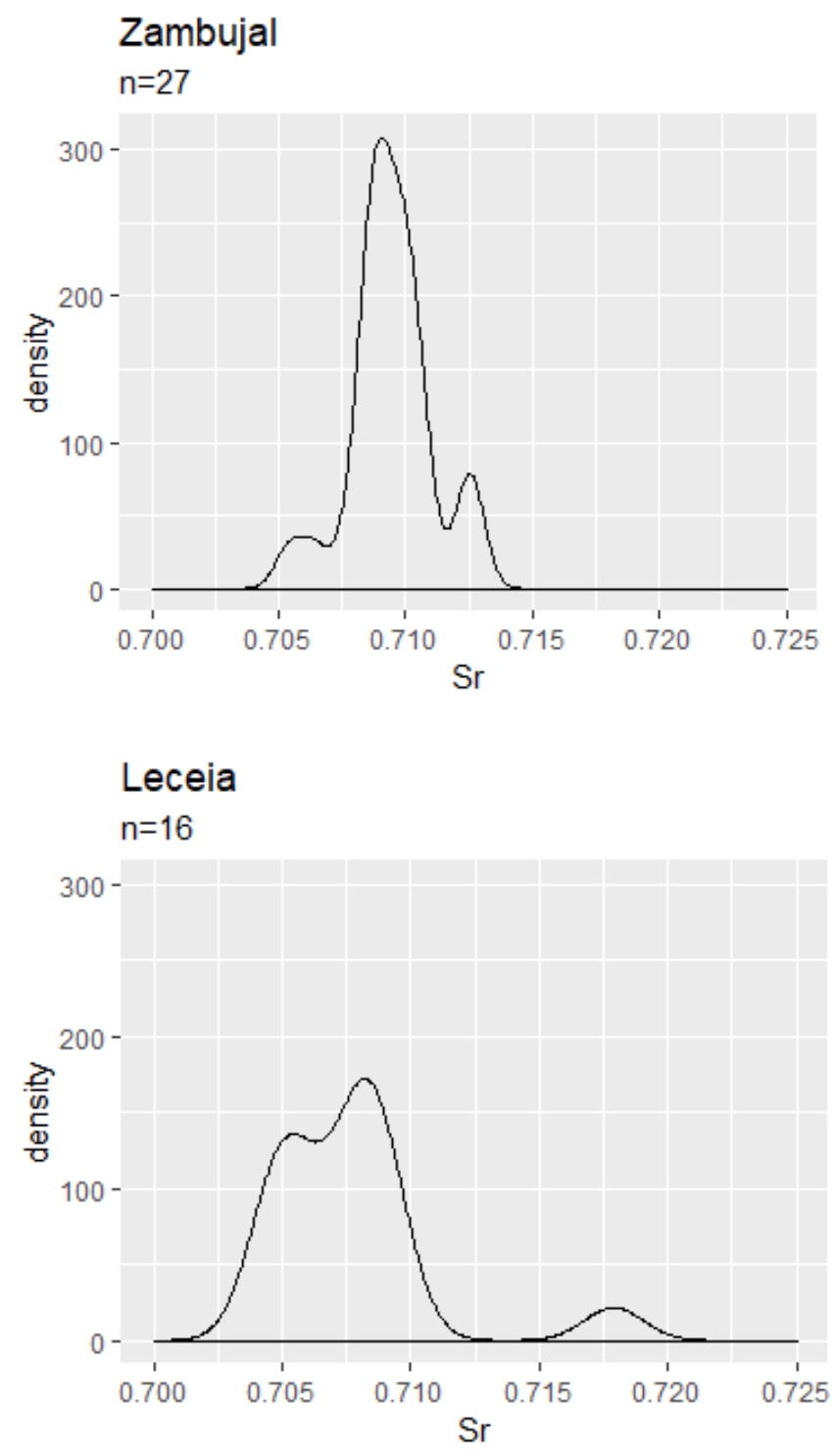

Figure 5: Density plots comparing ${ }^{87} \mathrm{Sr} /{ }^{86} \mathrm{Sr}$ enamel values between the two sites 


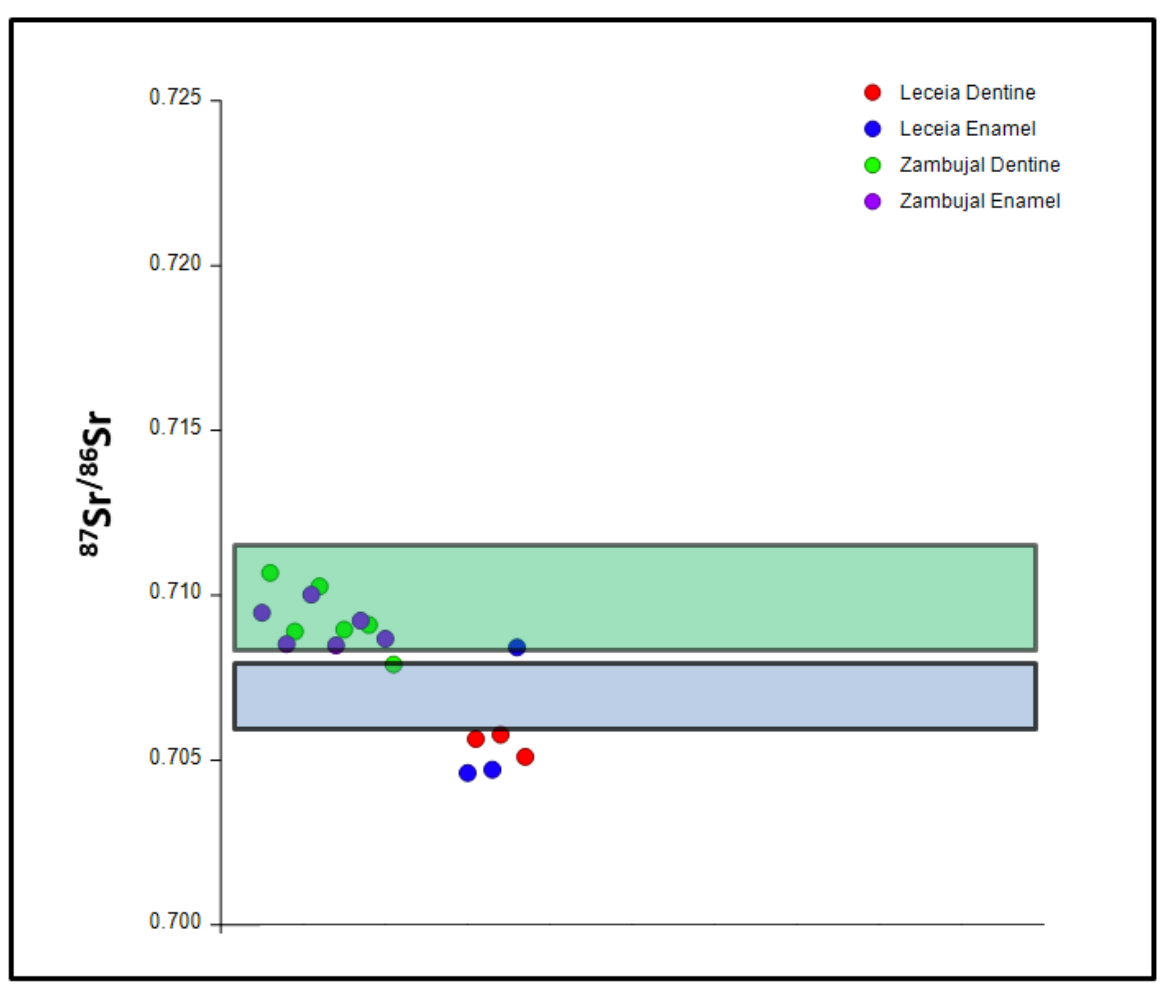

Figure 6: Plot showing ${ }^{87} \mathrm{Sr} /{ }^{86} \mathrm{Sr}$ values for enamel and dentine pairs. 


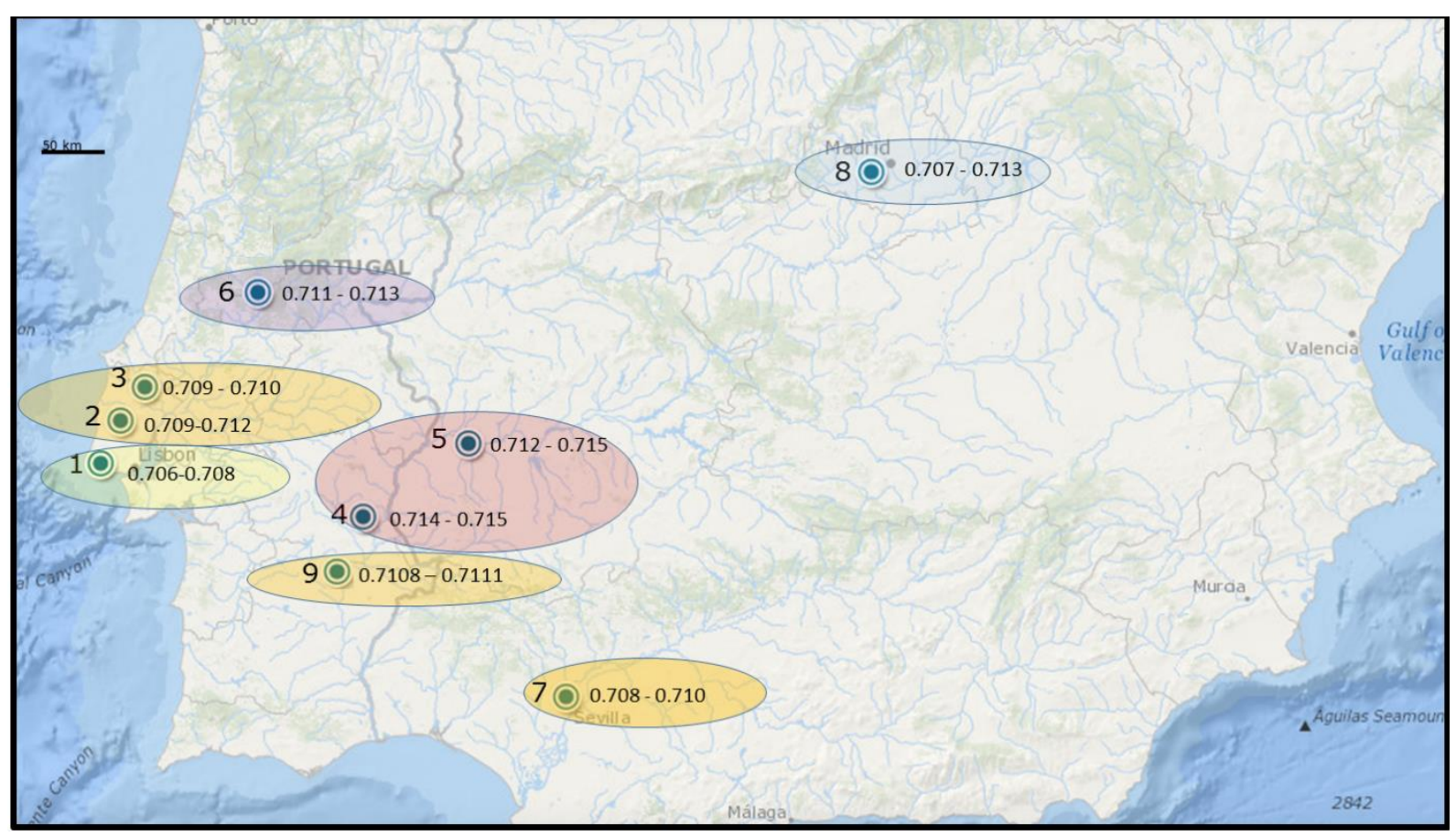

Figure 7: Sites listed in table with ${ }^{87} \mathrm{Sr} /{ }^{86} \mathrm{Sr}$ ranges. 1. Leceia, 2. Zambujal, 3. Bom Santo, 4. Perdigões, 5. La Pijotilla, 6. Rego da Murta I and II, 7. Valencina - Castilleja, 8. Madrid-region sites, 9. Monte da Cegonha 
Tables

Table 1: ${ }^{87} \mathrm{Sr} /{ }^{86} \mathrm{Sr}$ results from all samples

\begin{tabular}{|c|c|c|c|c|c|c|c|c|c|}
\hline Site & Genus & Cat \# & Type & ${ }^{87} \mathrm{Sr} /{ }^{86} \mathrm{Sr}$ & Site & Genus & Cat \# & Type & ${ }^{87} \mathrm{Sr} /{ }^{86} \mathrm{Sr}$ \\
\hline Zambujal & Bos & z807 & Enamel & 0.70960 & Leceia & Bos & L8 & Enamel & 0.70817 \\
\hline Zambujal & Bos & z1526 & Enamel & 0.71078 & Leceia & Bos & L10 & Enamel & 0.70695 \\
\hline Zambujal & Bos & z811 & Enamel & 0.70872 & Leceia & Bos & L16 & Enamel & 0.70560 \\
\hline Zambujal & Bos & z1499 & Enamel & 0.70872 & Leceia & Bos & L17 & Enamel & 0.70461 \\
\hline Zambujal & Bos & z932 & Enamel & 0.71024 & Leceia & Bos & L4 & Enamel & 0.70471 \\
\hline Zambujal & Bos & z1051 & Enamel & 0.70923 & Leceia & Bos & L19 & Enamel & 0.70494 \\
\hline Zambujal & Bos & z886 & Enamel & 0.70856 & Leceia & Bos & L27 & Enamel & 0.70524 \\
\hline Zambujal & Bos & zO00 & Enamel & 0.70900 & Leceia & Bos & L1 & Enamel & 0.70841 \\
\hline Zambujal & Bos & z1562 & Enamel & 0.71007 & Leceia & Bos & L6 & Enamel & 0.70817 \\
\hline Zambujal & Bos & z1464 & Enamel & 0.70920 & Leceia & Bos & L30 & Enamel & 0.71794 \\
\hline Zambujal & Bos & z643 & Enamel & 0.70868 & Leceia & Bos & L24 & Enamel & 0.70848 \\
\hline Zambujal & Bos & z1524 & Enamel & 0.71067 & Leceia & Bos & L9 & Enamel & 0.70547 \\
\hline Zambujal & Bos & z68051 & Enamel & 0.70643 & Leceia & Bos & L31 & Enamel & 0.70746 \\
\hline Zambujal & Bos & z1144 & Enamel & 0.70540 & Leceia & Bos & L52 & Enamel & 0.70938 \\
\hline Zambujal & Bos & z1225 & Enamel & 0.70766 & Leceia & Bos & $\mathrm{L} 2$ & Enamel & \begin{tabular}{|l}
0.70842 \\
\end{tabular} \\
\hline Zambujal & Bos & z591 & Enamel & 0.70863 & Leceia & Bos & L7 & Enamel & 0.70893 \\
\hline Zambujal & Bos & z803 & Enamel & 0.70963 & Leceia & Bos & L20 & Dentine & 0.70736 \\
\hline Zambujal & Bos & $z 62$ & Enamel & 0.71017 & Leceia & Bos & L17 & Dentine & 0.70564 \\
\hline Zambujal & Bos & 2778 & Enamel & 0.71228 & Leceia & Bos & L4 & Dentine & 0.70577 \\
\hline Zambujal & Bos & z68015 & Enamel & 0.71274 & Leceia & Bos & L5 & Dentine & 0.71227 \\
\hline Zambujal & Bos & z1814 & Enamel & 0.71256 & Leceia & Bos & L18 & Dentine & 0.70733 \\
\hline Zambujal & Bos & z971 & Enamel & 0.71032 & Leceia & Bos & L2 & Dentine & 0.70510 \\
\hline Zambujal & Bos & z1168 & Enamel & 0.70947 & Leceia & Oryctolagus & L9 & Bone & 0.70695 \\
\hline Zambujal & Bos & z1513 & Enamel & 0.70852 & Leceia & Oryctolagus & L6 & Bone & 0.70743 \\
\hline Zambujal & Bos & z68071 & Enamel & 0.71002 & Leceia & Oryctolagus & L3 & Bone & 0.70703 \\
\hline Zambujal & Bos & z1181 & Enamel & 0.70848 & Leceia & Leaf & $\begin{array}{l}\text { Leaf } \\
\text { L1 }\end{array}$ & & 0.70737 \\
\hline Zambujal & Bos & z155 & Enamel & 0.70951 & Leceia & Leaf & \begin{tabular}{|l} 
Leaf \\
L2
\end{tabular} & & 0.70738 \\
\hline Zambujal & Bos & z1168 & Dentine & 0.71068 & & & & & \\
\hline Zambujal & Bos & z1513 & Dentine & 0.70890 & & & & & \\
\hline Zambujal & Bos & z68071 & Dentine & 0.71027 & & & & & \\
\hline Zambujal & Bos & z1051 & Dentine & 0.70910 & & & & & \\
\hline Zambujal & Bos & z643 & Dentine & 0.70790 & & & & & \\
\hline Zambujal & Bos & z1042 & Dentine & 0.71042 & & & & & \\
\hline Zambujal & Bos & z1181 & Dentine & 0.70896 & & & & & \\
\hline Zambujal & Oryctolagus & z238401 & Bone & 0.70864 & & & & & \\
\hline Zambujal & Leaf & Leaf Z1 & & 0.70892 & & & & & \\
\hline Zambujal & Leaf & Leaf Z2 & & 0.70893 & & & & & \\
\hline
\end{tabular}


Table 2: Results from enamel and dentine pairs

\begin{tabular}{|l|l|l|r|r|}
\hline Site & Genus & Cat \# & ${ }^{87} \mathrm{Sr} /{ }^{86} \mathrm{Sr}$ Enamel & ${ }^{87} \mathrm{Sr} /{ }^{86} \mathrm{Sr}$ Dentine \\
\hline Zambujal & Bos & z1051 & $\mathbf{0 . 7 0 9 2 3}$ & $\mathbf{0 . 7 0 9 1 0}$ \\
\hline Zambujal & Bos & z643 & $\mathbf{0 . 7 0 8 6 8}$ & $\mathbf{0 . 7 0 7 9 0}$ \\
\hline Zambujal & Bos & z1168 & $\mathbf{0 . 7 0 9 4 7}$ & $\mathbf{0 . 7 1 0 6 8}$ \\
\hline Zambujal & Bos & z1513 & $\mathbf{0 . 7 0 8 5 2}$ & $\mathbf{0 . 7 0 8 9 0}$ \\
\hline Zambujal & Bos & z68071 & $\mathbf{0 . 7 1 0 0 2}$ & $\mathbf{0 . 7 1 0 2 7}$ \\
\hline Zambujal & Bos & z1181 & $\mathbf{0 . 7 0 8 4 8}$ & $\mathbf{0 . 7 0 8 9 6}$ \\
\hline Leceia & Bos & L17 & $\mathbf{0 . 7 0 4 6 1}$ & $\mathbf{0 . 7 0 5 6 4}$ \\
\hline Leceia & Bos & L4 & $\mathbf{0 . 7 0 4 7 1}$ & $\mathbf{0 . 7 0 5 7 7}$ \\
\hline Leceia & Bos & L2 & $\mathbf{0 . 7 0 8 4 2}$ & $\mathbf{0 . 7 0 5 1 0}$ \\
\hline
\end{tabular}


Table 3: Results of the Mann-Whitney $U$ test for differences in ${ }^{87} \mathrm{Sr} /{ }^{86} \mathrm{Sr}$ values between sites

\begin{tabular}{|l|l|l|l|l|}
\hline Site & $\mathbf{n}$ & W Sum ranks & $\mathbf{z}$ & $\mathbf{p}$ \\
\hline Zambujal & 27 & 738.50 & -3.631 & 0.000 \\
\hline Leceia & 16 & 207.50 & & \\
\hline Total & $\mathbf{4 3}$ & & & \\
\hline
\end{tabular}


Table $4:{ }^{87} \mathrm{Sr} /{ }^{86} \mathrm{Sr}$ 'local' values from sites across central and south west Iberia. *Local values are presented as given in the stated references, but are not always calculated in the same way. All ranges are given to three decimal places, with the exception of Monte Cegonha, which has a very small range.

\begin{tabular}{|c|l|l|l|}
\hline \# in Figure 7 & \multicolumn{1}{|c|}{ Area/site } & \multicolumn{1}{|c|}{ Local value* } & \multicolumn{1}{|c|}{ Reference } \\
\hline 1 & Leceia (Estremadura) & $0.706-0.708$ & This work \\
\hline 2 & Zambujal region (Estremadura) & $0.709-0.712$ & $\begin{array}{l}\text { Waterman et al. } \\
2014 \text {, and this work }\end{array}$ \\
\hline 3 & Bom Santo Cave (Estremadura) & $0.709-0.710$ & Carvalho et al. 2016 \\
\hline 4 & Perdigões (Alentejo) & $0.714-0.715$ & Žalaite et al. 2018 \\
\hline 5 & La Pijotilla (SW Spain) & $0.712-0.715$ & $\begin{array}{l}\text { Diaz-Zorita-Bonilla } \\
2013\end{array}$ \\
\hline 6 & $\begin{array}{l}\text { Rego da Murta I and II (Ribetejo } \\
\text { region, Estremadura) }\end{array}$ & $0.711-0.713$ & $\begin{array}{l}\text { Waterman et al. } \\
2013\end{array}$ \\
\hline 7 & Valencina-Castilleja (SW Spain) & $0.708-0.710$ & $\begin{array}{l}\text { Diaz-Zorita-Bonilla } \\
2013\end{array}$ \\
\hline 9 & $\begin{array}{l}\text { Sites near Madrid, Tagus Basin, } \\
\text { (Spain) }\end{array}$ & $0.707-0.713$ & Díaz-del-Río 2016 \\
\hline & Monte Cegonha & $0.7108-0.7111$ & Saragoça et al. 2016 \\
\hline & & & \\
\hline & & & \\
\hline
\end{tabular}

